\title{
COMPROMISE AND CONTESTATION Understanding the Drivers and Implications of Coalition Behaviour in Africa
}

\begin{abstract}
Danielle Resnick
Danielle Resnick was formerly a Research Fellow with the United Nations University-World Institute for Development Economics Research (UNUWIDER) and is currently a Research Fellow with the International Food

Policy Research Institute (IFPRI)

e-mail: D.Resnick@cgiar.org
\end{abstract}

\begin{abstract}
When and why do African political parties form electoral alliances? And how do these alliances translate into post-electoral governance and policymaking? To answer these questions, this article presents data on preelectoral coalitions for executive elections formed in all African countries between 1990 and 2013. Office-seeking motives overwhelmingly explain the goals of these coalitions but a variety of other factors, including two-round electoral systems, access to financing and the timing of coalition pacts, help determine whether such coalitions last until election day. Post-electoral coalitions have manifested in three main ways, including pre-electoral pacts that result in post-electoral Cabinet sharing, unity governments intended to end a political crisis, and parliamentary coalitions. The article concludes that while coalitions may occasionally lead to party turnover and end violent conflicts, their long-term consequences with regard to creating strong ties with voters, helping parties mature, encouraging more efficient policymaking and eliminating underlying sources of social contention remain more doubtful.
\end{abstract}

\section{INTRODUCTION}

When and why do African political parties form electoral alliances? And how do these alliances translate into post-electoral governance and policymaking? Addressing these questions is particularly important given the wide variety of coalitions that have been formed throughout the region in recent years. In addition, 
the promotion of coalitions is an increasing focus of the international democracy assistance community, particularly since funding coalitions allows donors not only to conserve scarce resources but also to promote inter-party cooperation and dialogue. For this reason the topic of coalition behaviour and its consequences is both of academic interest and relevant to policy.

Thus far, however, the literature on coalitions has been concentrated on more advanced democracies (see, eg, Baron \& Ferejohn 1989; Carroll \& Cox 2007; Debus 2009; Golder 2006a, 2006b; Laver \& Shepsle 1990; Müller \& Strøm 2000). In addition to the relatively short history of multiparty elections in Africa another reason for this gap is that the majority of African countries are presidential regimes, meaning that, in theory, the incentive for pre- and post-electoral coalition-building is much smaller than it is in parliamentary democracies. Nevertheless, there is a small but burgeoning area of research on African coalitions (see, eg, Arriola 2013a, 2013b; Cheeseman 2011; Cheeseman and Tendi 2010; Kadima 2006; Oyugi 2006; Resnick 2013a). Collectively, this scholarship presents a variety of hypotheses about the motivations and implications of such arrangements for party turnover, electoral volatility and party institutionalisation and for peace and reconciliation.

Using both quantitative and qualitative data this article builds upon this previous research in order to provide an overview of coalitions in Africa since the 1990s, examine factors that facilitate the formation of coalitions and consider the consequences of coalition governments. I find that pre-electoral coalitions form quite frequently in Africa even though the majority of the countries in the region are presidential regimes. This contradicts the expectations of a number of both comparativist and Africanist scholars, who believe that such regimes create disincentives for cooperation (see, eg, Linz 1990; Manning 2005; Valenzuela 1994).

Office-seeking motives overwhelmingly explain the goals of these coalitions but a variety of other factors, including two-round electoral systems, access to financing and the timing of coalition pacts, help determine whether such coalitions last until election day. Contrary to expectations, most coalitions formed by opposition parties are not successful in ousting incumbents.

Post-electoral coalitions are viewed as falling into one of three categories: coalitions in presidential regimes that result from pre-electoral negotiations and involve sharing Cabinet posts, unity governments formed to end a political crisis and violence and coalitions in parliamentary regimes. Existing research suggests that, aside from those in parliamentary regimes, post-electoral coalitions do not necessarily address the root causes of inter-party conflict nor do they facilitate quicker decision-making and policy continuity.

Before discussing these findings in greater detail, some definitional clarity is required. The terms 'alliance' and 'coalition' are used interchangeably here. 
Pre-electoral coalitions refer to two or more parties coalescing and coordinating their electoral strategies, with the expectation of sharing potential benefits in the event of victory at the polls (see Golder 2006a). In presidential regimes this results in parties jointly deciding to support one candidate, while in parliamentary ones it typically manifests as a commitment among multiple parties to compete under their own banner but not to field candidates in the same constituencies as their coalition partners.

A public electoral pact, especially by the formateur or selected coalition candidate/main party, may help to cement ex-ante the credibility of the distribution of any ex-post benefits. Post-electoral coalitions occur when two or more parties jointly lead government by virtue of shared cooperation at either the ministerial level or within Parliament.

As a result of this definition there are number of party configurations that are not considered coalitions. For instance, in this article, coalition does not refer to amalgamations of multiple societal actors under one banner. Thus, while the Movement for Multiparty Democracy (MMD) in Zambia was formed by a variety of labor union, civil society members, academics, and politicians, it was not the result of the fusion of two or more parties. ${ }^{1}$ In addition, parties that merged in the past and became new entities are not considered coalitions; rather, parties needed to retain their own separate identities and support bases despite working jointly with other parties and individuals. For example then, the Zimbabwe African National Union-Patriotic Front (Zanu-PF) would not be considered a coalition, even though the party originated from a merger in 1987 between the Zimbabwe African People's Union (Zapu) and the Zimbabwe African National Union (Zanu). By contrast, the ruling Ethiopian People's Revolutionary Democratic Front (EPRDF) is still an alliance of four separate parties and therefore constitutes a coalition.

With these definitional issues in mind, this article first presents a broad synthesis of all the pre-electoral coalitions that have taken place in the region since 1990. Subsequently, I discuss the various theories related to the formation and consequences of pre-electoral coalitions and test their applicability to the African party landscape. Using a variety of qualitative case studies I then discuss the drivers, significance and longevity of post-electoral coalitions. The final section concludes by discussing the article's main findings and highlighting remaining research gaps in the study of African party coalitions.

1 This approach differs from that of Arriola (2013a) and Kapa (2008), who both classify the MMD as a party coalition. 


\section{OVERVIEW OF PARTY COALITIONS IN AFRICA}

There are a number of advantages to forming pre-electoral party coalitions. In the African context, such alliances can help transcend ethno-linguistic or religious divisions and attract votes across societal groups (Horowitz 2002; Salih \& Nordlund 2007). More generally, they allow parties to pool resources and, especially for opposition parties, prevent incumbents from using 'divide and rule' tactics (see Howard \& Roessler 2006).

However, there is little optimism in the Africanist literature about the ability of parties to form coalitions. The fact that most regimes in Africa are presidential means that there is only one top 'prize' and party leaders are hesitant to forfeit the opportunity to obtain their country's highest position (see Manning 2005). Presidential regimes are generally believed not to be conducive to political cooperation (Linz 1990). As Valenzuela (1994, p 93) argues with reference to experiences in Latin America, 'the very rules of the presidential system often generated pressures that undermined the logic of coalition formation'. Moreover, the prominence of ethnic and religious cleavages is believed to hinder greater cooperation. According to Mozaffar \& Scarritt (2005), ethnic fragmentation hinders coordination by party leaders, who fear they may alienate their constituents by aligning with elites from other ethnic groups.

In order to examine patterns across the region with regard to coalition formation I aggregated data on pre-electoral coalitions formed in all African countries between 1990 and 2013. In doing so I focused specifically on executive elections because the motivations for joining a coalition for legislative elections can be quite different from those related to choosing a president or prime minister. Since the majority of African countries are presidential regimes, much of the focus is therefore on presidential elections. The only exceptions were for those five African countries (Botswana, Ethiopia, Lesotho, Mauritius, and South Africa) that are parliamentary regimes and where, therefore, the number of seats won by various parties determines who is ultimately appointed head of state.

This data builds on previous cross-national research in a number of ways. Specifically, Resnick (2013a) focused exclusively on the period from 2000 onwards, ignoring developments during the 1990s. Moreover, both Arriola (2013a) and Resnick (2013a) examined only opposition coalitions and limited their analysis to electoral democracies. Consequently, the use of coalitions by incumbents and in more circumscribed political regimes has been ignored. An important caveat, though, of this data is that it is based on election results and therefore overlooks pre-electoral coalitions that did not last until the election day. ${ }^{2}$

2 This data comes from the African Elections Database (africanelections.tripod.com), Arriola (2013), the International Foundation for Electoral Systems Election Guide (www.electionguide.org/), the InterParliamentary Union (IPU), and the Electoral Institute for Sustainable Democracy in Africa (EISA). 
Figure 1, which examines both incumbent (supporting a candidate who was already in office at the time and opposition coalitions or, for parliamentary regimes, the party to which the head of state belongs) debunks the notion that coalitions are rare or too difficult to form in Africa. In fact, 33 African countries have had at least one pre-electoral coalition since $1990 .{ }^{3}$ In total, 111 pre-electoral coalitions for executive elections have been formed that lasted until the election day. Figure $1 .{ }^{4}$ The number of pre-electoral coalitions, particularly among opposition parties, increased dramatically between the 1990s and the 2000s. This most likely reflects both an increase in the number of countries that allowed multiparty competition in the 2000s as well as the attendant growth in political parties resulting from more liberalised political environments.

\section{Figure 1}

\section{Number of Pre-Electoral Coalitions in Africa over Time}

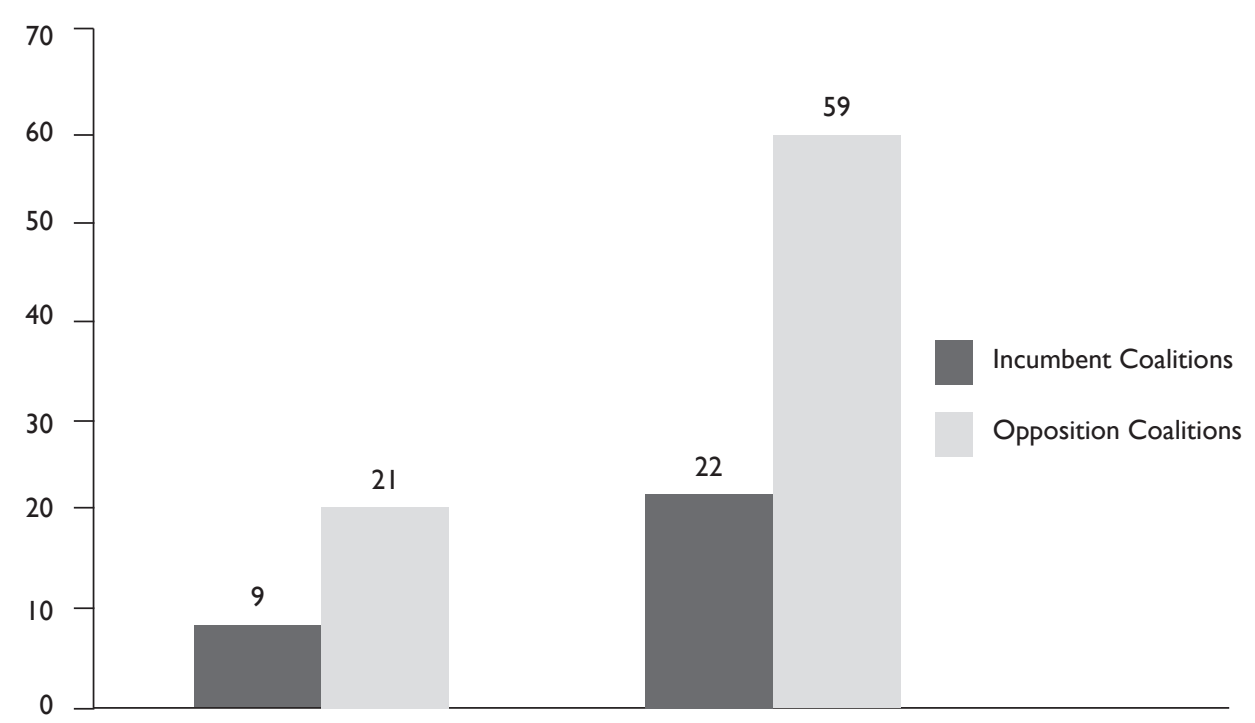

Source: Calculated by author using the sources detailed in footnote 2

3 Countries in which there were no pre-electoral coalitions or where coalitions did not remain united until election day include Burundi, Cameroon, Cape Verde, Chad, Equatorial Guinea, Eritrea, Guinea, Namibia, Niger, Rwanda, Sierra Leone, Sudan, Swaziland, and Zimbabwe.

4 In Mauritius, for example, if one of the parties that belonged to a coalition contained the party of the existing prime minister at the time of elections, it was coded as an incumbent coalition. 
Not surprisingly, coalitions tend to be more frequent in more open political environments because circumstances usually contribute to a higher number of participating parties. Figure 2 largely supports this by showing the relationship between the number of coalitions and the political rights ranking of a country during the year in which a coalition (or coalitions) were formed. The political rights ranking is from Freedom House and includes the electoral process, political pluralism and participation and the functioning of government. A ranking of 1 is best while a 7 indicates a highly restrictive political environment. While a large number of coalitions have been formed in countries with relatively open political environments, a not insignificant share have also emerged in more autocratic countries. Typically, such coalitions are either formed by incumbents that ally with much smaller and weaker parties in order to gain credibility or by a large share of opposition parties as they try collectively to oust an autocratic leader. Nevertheless, in extremely restrictive countries that limit multiparty competition, such as Eritrea, Equatorial Guinea, and Swaziland, there have been no coalitions.

Figure 2

Number of Coalitions by Degree of Political Rights

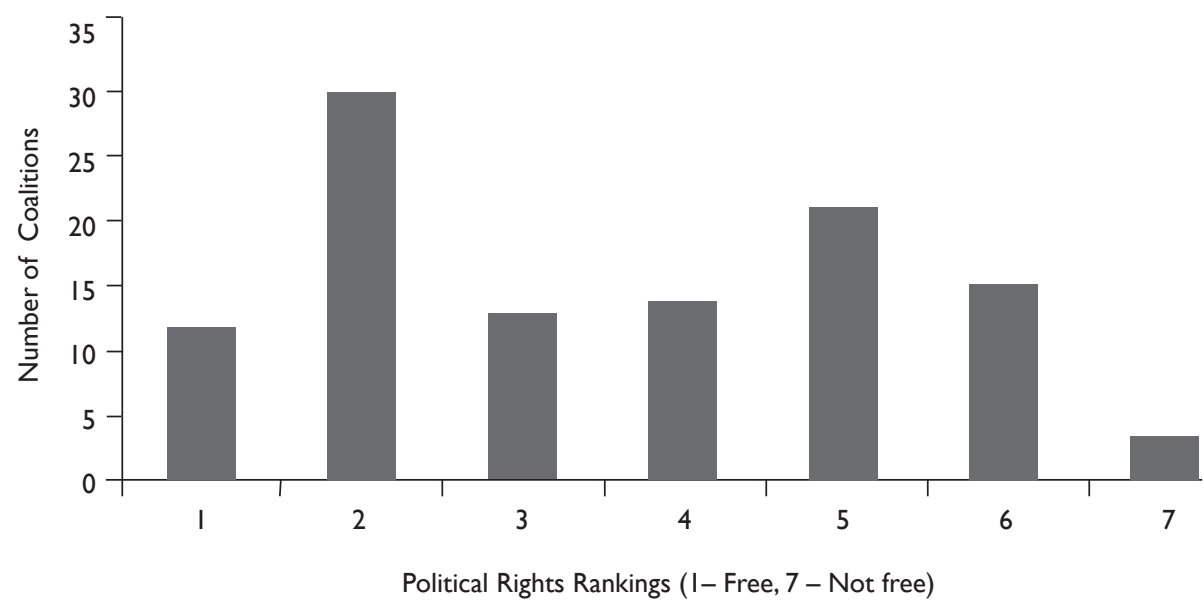

Source: Calculated by author using data sources detailed in footnote 2. Political rights rankings are from Freedom House.

Notes: This figure excludes the two Kenyan coalitions in 2013 because, at the time of writing, Freedom House data was unavailable for that year. 


\section{MOTIVATIONS FOR PRE-ELECTORAL COALITIONS}

Two key explanations are often given for why parties form coalitions. The first relates to office-seeking objectives. In this view, parties decide to join coalitions in order to gain control over the particular benefits, in terms of both power and material rewards, that accompany political office (see Budge \& Laver 1986; Laver \& Schofield 1990; Riker 1962; Strøm \& Müller 1999). The second explanation focuses more on policy-seeking objectives, emphasising that parties with similar ideologies are more likely to coalesce (De Swaan 1973). The reason for this may be the interest of the parties in influencing the post-electoral policy agenda or that a party's constituents are more likely to support a pre-electoral coalition if they do not need to make large policy concessions (see Budge \& Laver 1992; Golder 2006b).

In the African case, patronage is often advanced as an additional reason for coalition formation, especially by smaller parties that ally with an incumbent party (see, eg, Van de Walle 2007). In such cases, smaller parties may not expect to win many votes but instead hope for certain material incentives or Cabinet seats in return for supporting the incumbent.

Since a number of analysts (eg, Randall \& Svåsand 2002; Van de Walle \& Butler 1999) claim that African political parties rarely advance distinct policy agendas, most pre-electoral coalitions within the region are formed for officeseeking motives, especially in presidential regimes (see Rakner, Svåsand \& Khembo 2007). Yet, given that office-seeking is a goal of a majority of political parties, why do coalitions succeed in some countries and in some elections but not in others?

A rational explanation for when they occur is related to electoral expectations. For instance, Van de Walle (2006) argues that a coalition formation by opposition parties is equivalent to a 'tipping game', in that parties will only coalesce when they believe there is a realistic chance of victory. Otherwise, they are better off not opposing the ruling regime and potentially engaging in post-electoral bargaining with either the incumbent party or other opposition parties.

However, whether victory is realistic should plausibly be tied to the type of electoral rules governing the selection of an executive. According to Cox (1997), there are greater incentives for coalition formation in a plurality system than in a run-off system. Likewise, Kadima (2006) claims that first-past-the-post (FPTP) systems in particular place pressure on voters to avoid wasting their vote, thereby increasing the propensity of parties to form coalitions. By contrast, Rakner \& Van de Walle (2009) argue that coalitions are more likely in two-round systems (TRS) because candidates that lose in the first round tend to be more willing to 
support the party front-runners who make it to the second round (see also Van de Walle 2006). ${ }^{5}$

As seen in Figure 3 coalitions are much more likely to occur in TRS. ${ }^{6}$ Table 1 further indicates the number of coalitions by country and electoral system, highlighting that Senegal is the country with by far the most coalitions formed between 1990 and 2013. Importantly, however, under the TRS, many of the preelectoral coalitions were formed after the first round.

\section{Figure 3}

Number of Coalitions by Electoral System, 1990-2013

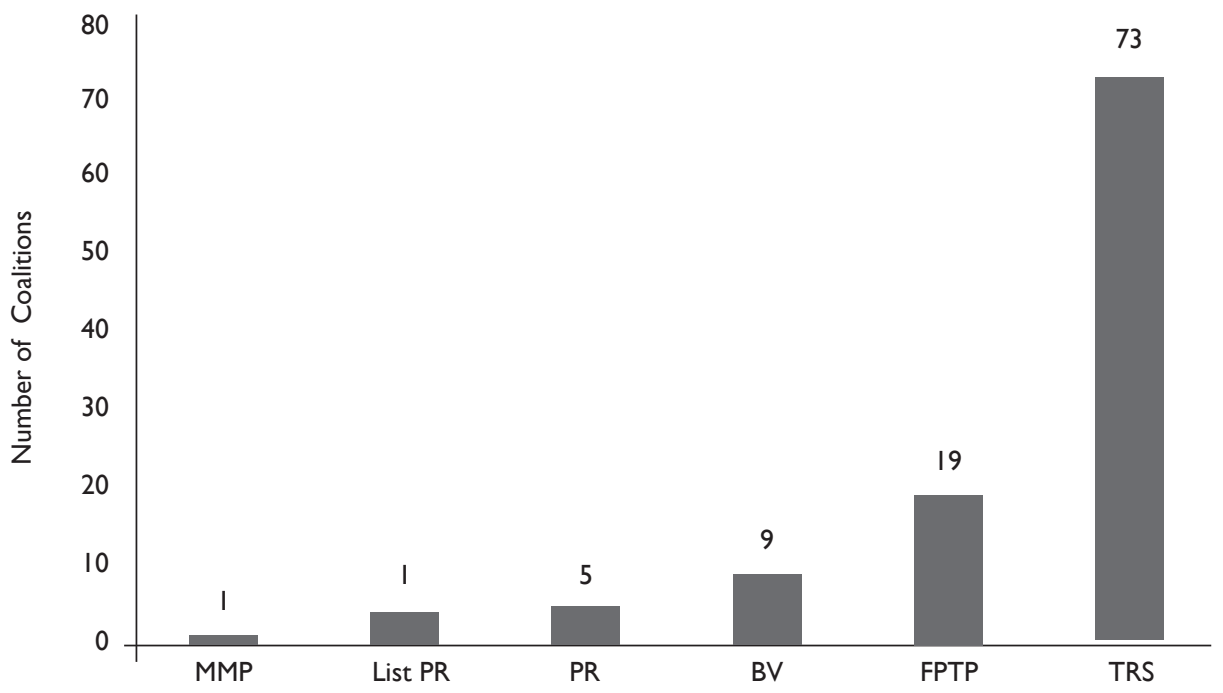

Source: Calculated by author using data sources detailed in footnote 2 .

5 In addition, some claim that disproportionality increases the likelihood of coalition formation. However, some (eg, Strøm, Budge \& Laver 1994; Golder 2006a, 2006b) believe this argument is more relevant for legislative elections.

6 Arriola (2013a) does not find that electoral institutions are statistically significant in explaining multiethnic, opposition party coalition formation. However, he only codes a multi-ethnic opposition coalition as existing if it was formed before the first round of voting in a TRS system. 
Table 1

Number of Coalitions by Country and Electoral System, 1990-2013

\begin{tabular}{|c|c|c|}
\hline Country & Number of coalitions & $\begin{array}{l}\text { Electoral system for executive } \\
\text { elections }\end{array}$ \\
\hline Senegal & 12 & TRS \\
\hline Mauritius & 9 & BV \\
\hline Ethiopia & 6 & FPTP \\
\hline Angola* & 5 & PR \\
\hline Benin & 5 & TRS \\
\hline Burkina Faso & 5 & TRS \\
\hline Gambia & 5 & TRS \\
\hline Liberia & 5 & TRS \\
\hline Mali & 5 & TRS \\
\hline Djibouti & 4 & TRS \\
\hline Ghana & 4 & TRS \\
\hline Kenya & 4 & TRS \\
\hline Madagascar & 4 & TRS \\
\hline Malawi & 4 & FPTP \\
\hline South Africa & 4 & List PR \\
\hline Congo-Brazzaville & 3 & TRS \\
\hline Mauritania & 3 & TRS \\
\hline Mozambique & 3 & TRS \\
\hline Botswana & 2 & FPTP \\
\hline Central African Republic & 2 & TRS \\
\hline Côte d'Ivoire & 2 & TRS \\
\hline Gabon & 2 & FPTP \\
\hline Tanzania & 2 & TRS \\
\hline Togo & 2 & FPTP \\
\hline Comoros & 1 & FPTP \\
\hline Congo-Kinshasa & 1 & FPTP \\
\hline Guinea-Bissau & 1 & TRS \\
\hline Lesotho & 1 & MMP \\
\hline Nigeria & 1 & TRS \\
\hline São Tome \& Principe & 1 & TRS \\
\hline Seychelles & 1 & TRS \\
\hline Uganda & 1 & TRS \\
\hline Zambia & 1 & FPTP \\
\hline
\end{tabular}

Source: Calculated by author using data sources detailed in footnote 2 .

Notes: Countries in boldface are parliamentary systems. *As of the 2010 constitution, Angola's president is elected by the party that obtains the majority of seats in Parliament. TRS - Two round system; BV Block vote; FPTP - First past the post; MMP - Mixed member plurality; PR -Proportional representation 
While the argument related to electoral institutions concerns why coalitions form in the first place, alternative explanations may be more valuable for understanding why coalitions that do form sometimes collapse before elections. According to Arriola (2013a), one reason why coalitions, particularly among opposition parties, emerge in some contexts is related to whether incumbents have exclusive control over financial capital. In more financially liberalised contexts, more resources are available to fund opposition campaigns than they are where most key industries are under state control. Using the examples of Kenya and Cameroon he highlights why the opposition was able to form the National Rainbow Coalition (NARC) in the former but why the Coalition pour la Réconciliation et la Reconstruction Nationale (CRRN) fell apart before elections in the latter.

In the same regard, the timing of the formation of a coalition can be relevant to its survival or collapse. In theory, an earlier formation can lead members to better articulate their common message, raise financial resources and increase awareness among the population. In practice, however, such forward planning gives the coalition more opportunity to fragment before elections as squabbles over leadership have time to emerge. A clear example is that of Zambia, where the Patriotic Front (PF) and the United Party for National Development (UPND) formed a pact in 2009. Approximately six months before the 2011 presidential election the pact collapsed as a consequence of squabbles between the parties' leaders, Michael Sata and Hakainde Hichilema, respectively, over who would be the pact's presidential candidate.

By contrast, the Mgwirizano coalition in Malawi was formed only three months before the 2004 elections and succeeded in staying together until election day (see Kadima \& Lembani 2006).

Much of the above discussion of pre-electoral coalition formation is related to opposition parties. Yet, as seen in Figure 1, there have been a sizeable number of incumbent coalitions. Given that incumbents typically have a resource advantage over the opposition, why would they ever choose to be part of a coalition? There appear to be three main trajectories. The first, which tends to occur predominantly in francophone countries, is the formation of alliances by independent presidential candidates who are presumably trying to gain credibility for their electoral bid without needing to be formally sponsored by a particular party. Key examples include the Union Pour la Majorite Presidentielle Plurielle that was formed around Yayi Boni in Benin in 2009, the Alliance for Democracy and Progress around Amadou Toumani Touré in Mali in 2007, and the National Convergence Kwa na Kwa formed around Francois Bozize in the Central African Republic for the 2005 elections.

The second reason is that, due to recent changes in electoral rules, uncertainty exists over an incumbent candidate's or party's electoral prospects if they 
competed independently. For example, in Congo-Brazzaville in 2002, changes to the Constitution created a more competitive environment that prompted Denis Sassou-Nguesso to enter a coalition. Blaise Compaoré's party, the Congress for Democracy and Progress (CDP), decided to enter a pre-electoral coalition known as the Presidential Movement Alliance for the 2002 presidential elections. According to Kapa (2008), pre-electoral coalitions were rare in Lesotho until the country switched to a mixed member proportional (MMP) system prior to the 2007 elections. As a result, the long-ruling Lesotho Congress for Democracy (LCD) formed an alliance with the National Independence Party (NIP).

The impact of electoral rules on the decision by incumbent regimes to form pre-electoral coalitions can be most pronounced in countries with substantial ethno-regional cleavages. One main example of this is the Ethiopian People's Revolutionary Democratic Front, which is the ruling alliance in Ethiopia and which is led by the Tigrayan People's Liberation Front (TPLF). Because Tigrayans are a minority population in Ethiopia they require cross-ethnic alliances with other parties in order to retain enough seats to dominate within Parliament.

A third trajectory relates to policy-seeking rather than office-seeking motives. The clearest example of this is South Africa's tripartite alliance between the African National Congress (ANC), the Confederation of South African Trade Unions (Cosatu), and the South African Communist Party (SACP). Both the SACP's and Cosatu's legitimacy and clout is enhanced by their alliance with the ANC. While the ANC would most likely still win elections without being part of this alliance, its policy and avowedly leftist credentials are enhanced by remaining within it.

\section{Consequences of pre-electoral coalitions}

The formation of coalitions has been broadly advocated for opposition parties as a strategy by which they can oust incumbents and contribute to party turnover (see, eg, Howard \& Roessler 2006; Van de Walle 2006). Fragmentation of the opposition is one of the key tactics used by incumbents, particularly in authoritarian regimes (Schedler 2002). Indeed, an oft-heard lament about African opposition parties is that they are unable to come together and present a united front (Arriola 2013b; Darnolf \& Holm 1999; Dorenspleet 2003; Joseph 1997). This viewpoint is often shared by African citizens. For instance, in the run-up to Malawi's 2004 elections, churches and civil society groups actively engaged in a process of negotiation and dialogue to arrive at a presidential candidate who could lead the Mgwirizano coalition (Rakner, Svåsand \& Khembo 2007).

Nevertheless, the empirical evidence suggests that coalitions only rarely contribute to opposition parties ousting incumbents (see Resnick 2013a). In fact, Figure 4 highlights that around $77 \%$ of incumbent coalitions have won the 
elections they contested, while the equivalent figure for opposition coalitions is only approximately $19 \%$. Appendix 1 presents the full details of these winning coalitions. The large proportion of incumbent coalitions that have been victorious is not especially surprising given that incumbents typically have an advantage in elections due to their access to state resources and greater name recognition among voters.

\section{Figure 4}

Winning Pre-Electoral Coalitions in Africa, 1990-2013

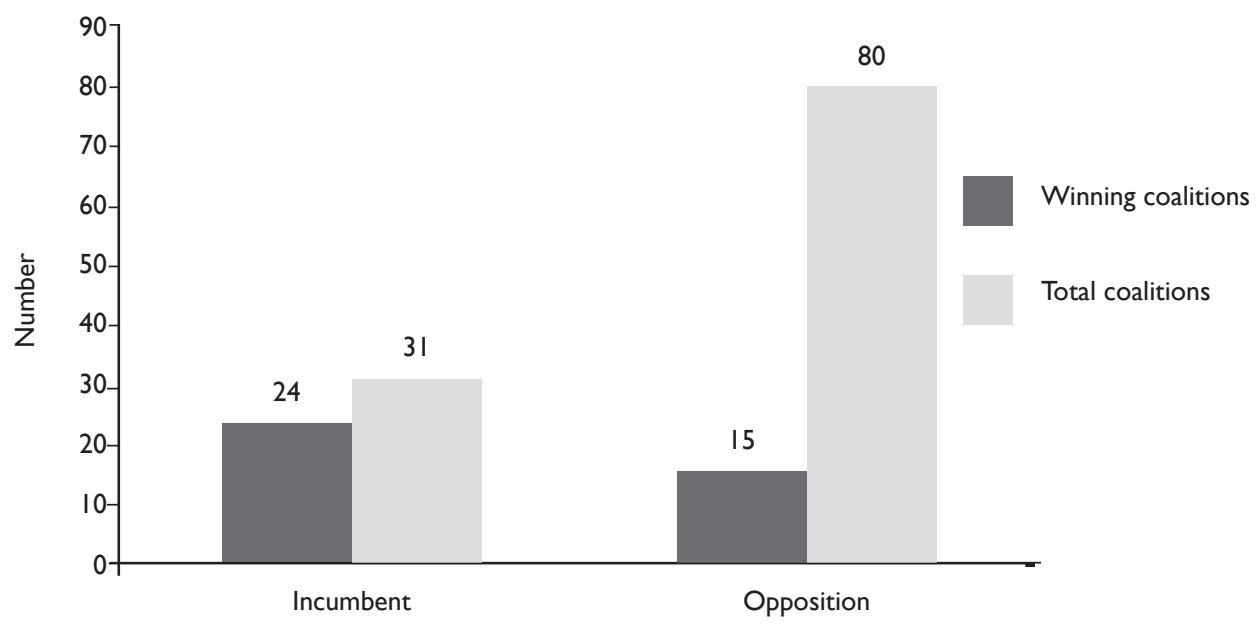

Source: Calculated by author using data sources detailed in footnote 2 .

Besides failing to contribute substantially to party turnover, coalitions can have deleterious effects on other aspects of democratic consolidation. As Resnick (2013a) highlights, they can be responsible for high levels of electoral volatility and reinforce low levels of party institutionalisation. Given the frequency with which they form and dissolve, coalitions fail to enable African parties to fortify their ties with particular constituents. Moreover, due to their office-seeking motivations, such coalitions typically result in strange bedfellows, with parties that competed against each other in previous elections subsequently coalescing. For instance, in Malawi, the United Democratic Front (UDF) formed a pact with the party it ousted during the country's first multiparty elections in 1994, the 
Malawi Congress Party (MCP). In Côte d'Ivoire in the 2010 elections Henri Bédié decided to support the candidacy of Alassane Ouattara under the banner of the Rally of Houphouetists for Democracy and Peace (RHDP). Ironically, however, Bédié had been a key promoter a decade earlier of the Ivoirité concept, whereby he tried to exclude Ouattara from competing as president because the latter's father originally came from Burkina Faso.

At the same time, there is the possibility that parties that previously worked together subsequently decide to compete against one another. In Mauritius, for example, the Labour Party (MLP) has alternatively been in coalition with the Mouvement Socialiste Militant (MSM) and the Mauritian Militant Movement (MMM), while also having competed against both those parties.

\section{POST-ELECTORAL COALITIONS: WHY DO THEY FORM? AND ARE THEY EFFECTIVE?}

In cases where pre-electoral coalitions are successful at the ballot box there are important implications for the longevity of post-electoral governance arrangements that vary according to political regime (see Table 2). In presidential regimes post-electoral coalitions typically involve sharing Cabinet positions. They are often the least sustainable type of post-electoral coalition because there is little to prevent the winning candidate from reneging on promises to coalition partners. As Mainwaring (1993, p 200) notes, 'incentives for parties to break coalitions are generally stronger in presidential regimes'.

For instance, Senegal's 2000 elections were historic because Abdoulaye Wade's Front pour l'Alternance (FAL) coalition ousted the long-ruling Socialist Party (PS). However, a year after coming to office Wade had ousted his prime minister, Moustapha Niasse, from the Alliance des Forces de Progrès (AFP) and dismissed a number of Cabinet members from other parties, including the Ligue Démocratique-Mouvement pour le Parti du Travail (LD-MPT) and the Parti de l'indépendance et du travail (PIT), which had supported his candidacy.

More recently, in Senegal, Macky Sall of the Alliance for the Republic (APR) was elected president in 2012 with the support of at least 14 other political parties in the second round of those elections. Subsequently, Cabinet seats were distributed among not only the APR but also the AFP, PS, and a party known as Rewmi, and the latter two parties complained about their small seat allocation (see Resnick forthcoming). Less than 18 months later Sall re-shuffled his Cabinet, purging five ministers. 
Table 2

Typology of Post-Electoral Coalitions

\begin{tabular}{|l|l|}
\hline Type & Examples (year of elections) \\
\hline $\begin{array}{l}\text { Post-electoral coalition in } \\
\text { presidential regime }\end{array}$ & $\begin{array}{l}\text { Malawi (1994), Kenya (2002), Senegal (2000, 2012), Côte } \\
\text { d'Ivoire (2010) }\end{array}$ \\
\hline $\begin{array}{l}\text { No pre-electoral coalition but } \\
\text { post-electoral unity government }\end{array}$ & Kenya (2007), Zimbabwe (2008) \\
\hline $\begin{array}{l}\text { Post-electoral coalition in } \\
\text { parliamentary regime }\end{array}$ & Ethiopia*, Lesotho (2012), Mauritius*, South Africa* \\
\hline
\end{tabular}

Note: * These countries have had multiple post-electoral coalitions

In Kenya Raila Odinga's Liberal Democratic Party (LDP) had been a critical coalition partner in the NARC coalition that supported Mwai Kibaki's presidency in the 2002 elections. Odinga was awarded a Cabinet position as Minister of Roads. However, he opposed Kibaki's attempt in 2005 to change the Constitution in order to strengthen presidential powers and he was subsequently purged from the Cabinet, along with a number of other members who had participated in NARC.

In contrast to presidential regimes, post-electoral coalitions in parliamentary regimes are the most sustainable, given that the stability of the government is more likely to be threatened if coalition partners rescind their support for one another. However, in Africa's five parliamentary regimes there appears to be a main difference according to whether there is a dominant party that plays the role of coalition formateur prior to elections. Specifically, in Ethiopia, the TPLF competes in elections as part of the EPRDF coalition and therefore has already made an $e x$ ante commitment to work with the other parties that are members of that coalition. Due to its dominance in Parliament, the EPRDF in turn has never needed to ally with additional parties in order to govern. Likewise, in South Africa, the ANC competes as part of a coalition with the SACP and therefore governs with that smaller party in the wake of elections and shares Cabinet positions accordingly. In turn, the dominance of the ANC in elections means that it has not yet needed to work with additional parties in order to rule.

A different dynamic prevails in the parliamentary regimes of Mauritius and Lesotho, where no one party is dominant. In Mauritius parties tend to reflect a mixture of both ethno-linguistic characteristics and diverse policy orientations. There are two main parties, the LP and the MMM, but also a variety of smaller yet still influential entities, including the MSM and the PMSD. Since independence the country has been governed by a coalition of at least two parties (Sithanen 
2003). A key reason for this has been the country's unique electoral system, which is organised according to a three-member constituency, FPTP system and a best loser system that creates incentives for cross-ethnic collaboration (Sithanen 2003; Kadima \& Kasenally 2006). ${ }^{7}$ In contrast to the situation in Ethiopia or South Africa, a number of coalition governments in Mauritius have collapsed, including the MSM-MMM alliance in 1991, the LP-MMM coalition in 1995 and the Alliance of the Future in 2011.

While most of the governing coalitions in the above cases differ from Western European parliamentary regimes in that they have already been determined prior to elections (see Kadima 2006), Lesotho represents an interesting exception. In Lesotho the long-ruling dominance of the LCD was overturned in the 2012 elections, resulting in the Democratic Congress (DC) gaining the most seats. However, it still lacked enough seats to form a government and instead the party with the next highest number of seats, the All Basotho Convention (ABC), formed a government with the LCD and the Basotho National Party (BNP) (see EISA 2012). The uncertainty surrounding post-electoral coalition-building in the Lesotho case is most likely due to parties still learning how to strategise around the new MMP electoral rules and the recent growth in political parties due to internal rifts in recent years.

In terms of sustainability, governing coalitions formed as a consequence of electoral strife tend to occupy an interim position. Although there have been examples in other post-conflict settings such as Afghanistan, Honduras, and Iraq, such arrangements have been relatively specific to the African context. Most recently, a power-sharing arrangement has been promoted by the African Union, the United Nations and the Southern African Development Community as a solution to Madagascar's ongoing governance crisis, precipitated when President Marc Ravalomanana was overthrown by the mayor of Antananarivo, Andry Rajoelina.

Under such arrangements, typically known as unity governments, Cabinet positions are shared among all major parties involved in conflict. They are usually focused on a narrow set of goals that involve ending violence and planning a timetable for fresh elections (Cheeseman 2011). In order to encourage unity governments, the international donor community typically makes the disbursement of funding contingent on such arrangements.

Two of the most notable power-sharing arrangements have taken place in Zimbabwe and Kenya after divisive and chaotic elections in 2008 and 2007, respectively. In both, Cabinet posts were roughly equally distributed between the

7 More specifically, the best loser system returns eight members of Parliament in those communities that are under-represented in Parliament (see Sithanan 2003). 
ruling party and the opposition. Both Robert Mugabe and Mwai Kibaki refused to give up the presidency, so the opposition leaders in each country, Morgan Tsvangirai and Raila Odinga, were given the office of prime minister. In Zimbabwe, the opposition Movement for Democratic Change (MDC) also obtained the prestigious Cabinet post of finance minister for Tendai Biti (see Cheeseman \& Tendi 2010). Other examples of power-sharing have occurred in Angola, Burundi, the Democratic Republic of Congo and South Africa.

\section{Implications of post-electoral coalitions}

The implications of post-electoral coalitions can be examined with respect to peace and stability as well as policy efficiency. As noted above, unity governments are, in theory, established to promote peace and stability. However, the existing research is not especially optimistic. Cheeseman (2011) addresses this issue by focusing specifically on the ability of coalition governments to address security sector reforms. He finds that the success of unity governments in these domains depends on the level of elite trust and the distribution of violence, which refers to whether one or multiple parties have committed atrocities. In his analysis, South Africa represents a unique case because the National Party and the ANC could agree on a modest transformative agenda as the country made the transition from apartheid rule. By contrast, such arrangements in Angola, Burundi, the DRC, Kenya, and Zimbabwe have failed to lead to meaningful reforms that would prevent future conflict. In the latter two cases in particular, the unity governments lasted for an entire electoral term, but partisan divisions remained sharp, leading to the pessimistic conclusion that 'Rather than create space for reform coalitions, power-sharing can be manipulated by incumbents desperate to retain their positions in the face of electoral defeat, undermining the prospects for reconciliation or institutional regeneration' (Cheeseman \& Tendi 2010, p 207).

Another challenge for post-electoral coalitions more generally is policy effectiveness. Coalition governments in parliamentary regimes are typically believed to be more deadlocked by competing party perspectives and therefore less efficient in making decisions (see Hagan 1993). In the African context this appears to be truer in the case of coalitions in Mauritius and Lesotho, where the lack of a dominant party in recent elections prompted post-electoral coalitions, than in Ethiopia or South Africa, where there is a dominant party.

In Africa's presidential regimes a post-electoral coalition is still dominated by the policy preferences of the executive and therefore there is little to hinder the speed with which decisions are made. However, if such coalitions collapse, the ensuing Cabinet re-shuffles can contribute to high levels of policy instability within specific sectors as new ministers try to make their mark. In Senegal, for 
example, the former president, Wade, had seven different agriculture ministers during his tenure as a result of fissions within post-electoral alliances, which, in turn, hindered any policy continuity in that sector (Resnick 2013b).

\section{CONCLUSION}

Electoral coalitions are an increasing phenomenon in Africa, especially since the onset of multiparty politics in much of the region in the early 1990s. Although there has been a recent spate of research on coalitions in Africa, this article is the first to provide a synthesis of dynamics across both democratic and autocratic countries as well as presidential and parliamentary regimes. In addition, it has examined pre-and post-electoral coalitions among both incumbent and opposition parties.

In general, I found that pre-electoral coalitions are more frequent than would be expected from the literature on presidential regimes, even though the majority of African countries fall into this category. But, contrary to the expectations of other Africanist scholars, such coalitions are rarely a successful strategy for ousting incumbents. Moreover, they often collapse in the post-electoral period, unless they were part of a unity government or formed in a parliamentary system. Encouraging parties to participate in unity governments in post-conflict contexts is difficult, as shown by the collapse of efforts in Madagascar in 2009. But even where such coalition governments do prevail, there is little evidence outside of South Africa that they reduce the underlying tensions that could contribute to a resurgence of conflict in the near future.

While a majority of research has focused on the drivers of coalition formation and collapse, the implications of coalitions in Africa constitute an area for much greater analysis. Two possible areas for inquiry relate to policy substance and democratic legitimacy. In other areas of the world, coalitions are found to exhibit different foreign policy behaviours (Kaarbo 2012) and economic policy orientations (see, eg, Edin \& Ohlsson 1991).

Thus far there has been no systematic examination of whether coalition governments in Africa display markedly different behaviours in such domains than non-coalition governments. In addition, there has been little analysis of how African citizens view the legitimacy of coalitions. Journalistic accounts tend to highlight a preference by African voters for pre-electoral coalitions of opposition parties, especially in countries where incumbents have been difficult to dislodge. But thus far no survey research has been conducted into how voters actually perceive pre-electoral coalitions. Furthermore, in the European context, there have been studies suggesting that governing coalitions are viewed as less accountable for their performance, especially with respect to the economy, because no one party can be directly blamed for policy decisions (see Samuels 2004). However, 
an analysis of governing coalitions, particularly unity governments and coalitions in parliamentary regimes, and perceptions of accountability still remains a key knowledge gap in the African context.

Overall, the existing research presented in this article suggests that expectations of the potential of coalitions should be tempered. On the one hand, the growing number of parties that have been willing to come together, and stay together for long enough to compete in elections offers optimism about the prospects of inter-party cooperation. On the other hand, given that most preelectoral coalitions in Africa are formed for the purpose of office-seeking rather than for promoting particular policies, they rarely transform parties into more institutionalised and robust entities.

Pre-electoral coalitions that include incumbents may even perpetuate the status quo by co-opting smaller parties through patronage and the distribution of offices. Thus, while coalitions may, in the short term, occasionally lead to party turnover and end violent conflicts, their long-term consequences with regard to creating strong ties with voters, helping parties mature, encouraging more efficient policymaking and eliminating underlying sources of social contention remain much more doubtful. 


\section{APPENDIX \\ Winning Coalitions in Africa, 1990-2013}

\begin{tabular}{|c|c|}
\hline Incumbent Coalition/Pact/Alliance & Country (Year) \\
\hline $\begin{array}{l}\text { New Benin Alliance (Alliance du Benin Nouveau- } \\
\text { ABN) }\end{array}$ & Benin (2006) \\
\hline $\begin{array}{l}\text { Union pour la majorité presidentielle plurielle } \\
\text { (UMPP) }\end{array}$ & Benin (2011) \\
\hline Presidential Movement Alliance & Burkina Faso $(2005,2010)$ \\
\hline National Convergence 'Kwa na Kwa' & Central African Republic (2005) \\
\hline $\begin{array}{l}\text { Congolese Work Party-United Democratic Forces } \\
\text { (PCT-FDU) }\end{array}$ & Congo-Brazzaville (2002) \\
\hline Rally of the Presidential Majority & Congo-Brazzaville (2009) \\
\hline RPP-FRUD & Djibouti (2000) \\
\hline Union for the Presidential Majority (UMP) & Djibouti $(2005,2010)$ \\
\hline $\begin{array}{l}\text { Ethiopian People's Revolutionary Democratic } \\
\text { Front (EPRDF) }\end{array}$ & Ethiopia $(2000,2005,2010)$ \\
\hline New Alliance & Gabon (1993) \\
\hline Progressive Alliance & Ghana $(1992,1996)$ \\
\hline Party of National Unity & Kenya (2007) \\
\hline MSM-MMM & Mauritius (1991) \\
\hline Alliance of the Future & Mauritius (2010) \\
\hline Coalition Sopi 2007 & Senegal (2007) \\
\hline Tripartite Alliance & South Africa $(1994,1999,2004,2009)$ \\
\hline Opposition Coalition/Pact/Alliance & Country (Year) \\
\hline $\begin{array}{l}\text { Union pour le Triomphe du Renouveau } \\
\text { Democratique (UTRD) }\end{array}$ & Benin (1991) \\
\hline FARD-Alafia-NCC-RDL-Vivoten Pact & Benin (1996) \\
\hline $\begin{array}{l}\text { Rally of Houphouetists for Democracy and Peace } \\
\text { (RHDP) }\end{array}$ & Côte d'Ivoire (2010) \\
\hline National Rainbow Coalition (NARC) & Kenya (2002) \\
\hline Jubilee Coalition & Kenya (2013) \\
\hline Forces Vives Rasalama (FVR) & Madagascar (1992) \\
\hline Crisis Cell Alliance & Madagascar (2001) \\
\hline Common Electoral Group & Malawi (1994) \\
\hline $\begin{array}{l}\text { Alliance for Democracy in Mali-Pan African Party } \\
\text { for Liberty, Solidarity, and Justice (ADEMA-PASJ) }\end{array}$ & Mali (1992) \\
\hline
\end{tabular}




\begin{tabular}{|l|l|}
\hline Pact around Amadou Toumani Touré & Mali (2002) \\
\hline MLP-MMM & Mauritius (1995) \\
\hline MMM-MSM & Mauritius (2000) \\
\hline Social Alliance & Mauritius (2005) \\
\hline Alternative 2000 coalition & Senegal (2000) \\
\hline Macky 2012 & Senegal (2012) \\
\hline
\end{tabular}

Note: Incumbent and opposition coalitions for Mauritius were designated by examining the party from which the prime minister came.

\section{- REFERENCES}

Arriola, L. 2013a. 'Capital and opposition in Africa: Coalition building in multiethnic societies'. World Politics 65(2).

Arriola, L. 2013b. Multiethnic Coalitions in Africa: Business Financing of Opposition Election Campaigns. New York: Cambridge University Press.

Baron, D \& J Ferejohn. 1989. 'Bargaining in Legislatures'. American Political Science Review 83.

Budge, I \& M Laver. 1986. 'Office Seeking and Policy Pursuit in Coalition Theory'. Legislative Studies Quarterly 11.

Budge, I \& M Laver (eds). 1992. Party Policy and Coalition Policy in Europe. London: Macmillan, New York: St. Martins.

Carroll, R \& G Cox. 2007. 'The Logic of Gamson's Law: Pre-electoral Coalitions and Portfolio Allocations'. American Journal of Political Science 51.

Cheeseman, N. 2011. 'The internal dynamics of power-sharing in Africa'. Democratization 18(2).

Cheeseman, N \& B-M Tendi. 2010. 'Power-sharing in comparative perspective: The dynamics of "unity government" in Kenya and Zimbabwe'. Journal of Modern African Studies 48 (2).

Cox, G W. 1997. Making Votes Count: Strategic Coordination in the World's Electoral Systems. Cambridge: Cambridge University Press.

Darnolf, S \& J D Holm. 'Democracy without a credible opposition: The case of Botswana'. The Journal of African Policy Studies 5(2\&3).

Debus, M. 2009. 'Pre-electoral Commitments and Government Formation'. Public Choice 138.

De Swaan, A. 1973. Coalition Theories and Cabinet Formation. Amsterdam: Elsevier. Doorenspleet, R. 2003. 'Political Parties, Party Systems and Democracy in SubSaharan Africa. In M A M Salih (ed). African Political Parties: Evolution, Institutionalisation and Governance. London: Pluto Press. 
Edin, P-A \& H Ohlsson. 1991. 'Political determinants of budget deficits: Coalition effects versus minority effects'. European Economic Review 35(8).

Electoral Institute for Sustainable Democracy in Africa (EISA). 2013. EISA Election Observer Mission Report: Parliamentary Elections, 26 May 2012, Lesotho. Johannesburg: EISA.

Golder, S. 2006a. 'Pre-electoral coalition formation in parliamentary democracies'. British Journal of Political Science 36.

Golder, S. 2006b. The Logic of Pre-electoral Coalition Formation. Columbus, OH: Ohio State University Press.

Hagan, J. 1993. Political Opposition and Foreign Policy in Comparative Perspective. Boulder, CO: Lynne Rienner.

Horowitz, D. 2002. 'Constitutional Design: Proposals versus Processes'. In A Reynolds (ed). The Architecture of Democracy: Constitutional Design, Conflict Management, and Democracy. New York: Oxford University Press.

Howard, M \& P Roessler. 2006. 'Liberalizing Electoral Outcomes in Competitive Authoritarian Regimes'. American Journal of Political Science 50.

Joseph, R. 1997. 'Democratization in Africa after 1989: Comparative and Theoretical Perspectives. Comparative Politics 29 (3).

Kaarbo, J. 2012. Coalition Politics and Cabinet Decision Making: A Comparative Analysis of Foreign Policy Choices. Ann Arbor, MI: University of Michigan Press.

Kadima, D (ed). 2006. The Politics of Party Coalitions in Africa. Johannesburg: Konrad Adenauer Foundation and EISA.

Kadima, D \& S Lembani. 2006. 'Making, Unmaking and Remaking Political Party Coalitions in Malawi: Explaining the Prevalence of Office-Seeking Behavior'. In D Kadima (ed). The Politics of Party Coalitions in Africa. Johannesburg: Konrad Adenauer Foundation and EISA.

Kapa, M A. 2008. 'The Politics of Coalition Formation and Democracy in Lesotho'. Politikon 35(3).

Laver, M \& K Shepsle. 1990. 'Coalitions and Cabinet Government'. American Political Science Review 84.

Laver, M \& N Schofield. 1990. Multiparty Government: The Politics of Coalition Government in Europe. Oxford: Oxford University Press.

Linz, J. 1990. 'The Perils of Presidentialism'. Journal of Democracy 1(1).

Mainwaring, S. 1993. 'Presidentialism, Multipartism, and Democracy: The Difficult Combination'. Comparative Political Studies 26.

Manning, C. 2005. 'Assessing African Party Systems after the Third Wave.' Party Politics 11(6).

Mozaffar, S \& J E Scarritt. 2005. 'The Puzzle of African Party Systems'.Party Politics 11(4). 
Müller, W C \& K Strøm (eds). 2000. Coalition Governments in Western Europe. Oxford: Oxford University Press.

Oyugi, W. 2006. 'Coalition politics and coalition governments in Africa'. Journal of Contemporary African Studies 24(1).

Rakner, L, L Svåsand \& N Khembo. 2007. 'Fissions and Fusions, Foes and Friends: Party Systems Restructuring in Malawi in the 2004 General Elections'. Comparative Political Studies 40.

Rakner, L \& N van de Walle. 2009. 'Democratization by Elections? Opposition Weakness in Africa'. Journal of Democracy 20.

Randall, V \& L Svåsand. 2002. 'Political Parties and Democratic Consolidation in Africa'. Democratization 9.

Resnick, D. 2013a. 'Do electoral coalitions facilitate democratic consolidation in Africa?' Party Politics 19(5).

Resnick, D. 2013b. 'Personalistic policymaking in a vibrant democracy: Senegal's fragmented response to the 2007 / 08 food price crisis'. UNU-WIDER Working Article No. 2013/015. Helsinki, Finland: UNU-WIDER.

Resnick, D. Forthcoming. 'Continuity and change in Senegalese party politics: Lessons from the 2012 elections'. African Affairs. doi: 10.1093/afraf/adt049

Riker, W. 1962. The Theory of Political Coalitions. New Haven, CT: Yale University Press.

Salih, M, A Mohamed \& P Nordlund. 2007. Political Parties in Africa: Challenges for Sustained Multiparty Democracy. Stockholm: International Institute for Democracy and Electoral Assistance.

Samuels, D. 2004. 'Presidentialism and Accountability for the Economy in Comparative Perspective'. American Political Science Review 98(3).

Schedler, A. 2002. 'Elections without Democracy: The Menu of Manipulation'. Journal of Democracy 13(2).

Sithanen, R. 2003. 'Coalition politics under the tropics: Office seekers, power makers, nation building: A case study of Mauritius'. Paper presented at EISA Roundtable on Political Party Coalitions, Cape Town, South Africa, June 19.

Strøm, K, I Budge \& M Laver. 1994. 'Constraints on cabinet formation in parliamentary democracies'. American Political Science Review 79.

Strøm, K \& W C Müller. 1999. ‘Political Parties and Hard Choices. In W C Müller \& K Strøm (eds). Policy, Office, or Votes?: How Political Parties in Western Europe Make Hard Choices. Cambridge: Cambridge University Press.

Valenzuela, A. 1994. 'Party Politics and the Crisis of Presidentialism in Chile: A Proposal for a Parliamentary Form of Government'. In J Linz \& A Valenzuela (eds). The Failure of Presidential Democracy. Baltimore, MD: Johns Hopkins University Press. 
Van de Walle, N. 2006. 'Tipping Games: When Do Opposition Parties Coalesce?'. In A Schedler (ed). Electoral Authoritarianism. Boulder, CO: Lynne Rienner.

Van de Walle, N. 2007. 'Meet the New Boss, Same as the Old Boss? The Evolution of Political Clientelism in Africa'. In H Kitschelt and S I Wilkinson (eds). Patrons, Clients, and Policies: Patterns of Democratic Accountability and Political Competition. Cambridge. UK: Cambridge University Press.

Van de Walle, N \& K Butler. 1999. 'Political Parties and Party Systems in Africa's Illiberal Democracies'. Cambridge Review of International Affairs 13. 